\title{
Penerapan Model Problem Based Learning untuk Meningkatkan Hasil Belajar Pendidikan Agama Islam Siswa Sekolah Dasar
}

\author{
Irnawati $^{1}$, Yusrizal Efendi ${ }^{2}$, Mega Adyna Movitaria ${ }^{3}$ \\ ${ }^{1}$ UPTD SDN 01 Mungka, Indonesia \\ ${ }^{1}$ Institut Agama Islam Negeri Batusangkar, Indonesia \\ ${ }^{1}$ Institut Agama Islam Sumbar Pariaman, Indonesia \\ e-mail: irnawatihabib24@gmail.com, yusrizalefendi@iainbatusangkar.ac.id, megaadyna@iaisumbar.ac.id
}

Submitted: 22-08-2021 Revised : 30-10-2021Ａccepted: 05-11-2021

\begin{abstract}
This article aims to describe the improvement of learning outcomes for Religious Education and Character Education (PAIdBP) by using the Problem Based Learning model in class V UPTD SDN 01 Mungka. The type of research is Classroom Action Research (CAR) using qualitative and quantitative approaches. The research subjects were 22 students of class V UPTD SDN 01 Mungka. The data in this study are student learning outcomes at the end of each cycle. The resulting data is processed and analyzed descriptively qualitatively. The conclusion of the study shows that the use of the Problem Based Learning model can improve student learning outcomes in PAIdBP learning, this can be seen from the student learning outcomes in the first cycle, which is 80.44 increasing to 85.06 in the second cycle.
\end{abstract}

Keywords: Learning Outcomes, Problem Based Learning, Islamic Religious Education,

ABSTRAK. Artikel ini bertujuan untuk mendeskripsikan peningkatan basil belajar Pendidikan Agama dan Budi Pekerti (PAIdBP) dengan menggunakan model Problem Based Learning di kelas V UPTD SDN 01 Mungka. Jenis penelitian adalab Penelitian Tindakan Kelas (PTK) dengan menggunakan pendekatan kualitatif dan kuantitatif. Subjek penelitian adalab 22 orang peserta didik kelas V UPTD SDN 01 Mungka. Data dalam penelitian ini adalab hasil belajar peserta didik pada akbir masing-masing siklus. Data yang dihasilkan diolah dan dianalisis secara deskriptif kualitatif. Simpulan penelitian menunjukkan bahwa penggunaan model Problem Based Learning dapat meningkatkan hasil belajar peserta didik pada pembelajaran PAIdBP, hal ini terlihat dari hasil belajar peserta didik siklus I yaitu 80,44 meningkat menjadi 85,06 pada siklus II.

Kata Kunci: Hasil Belajar, Problem Based Learning, Pendidikan Agama Islam

\section{doi Https://doi.org/10.54069/attadrib.v4i2.144}

How to Cite Irnawati, Efendi, Y., Movitaria, MA. (2021). Penerapan Model Problem Based Learning untuk Meningkatkan Hasil Belajar Pendidikan Agama Islam Siswa Sekolah Dasar. Attadrib: Jurnal Pendidikan Guru Madrasah Ibtidaiyah, Vol 4 (2), 81-88

\section{PENDAHULUAN}

Perkembangan pendidikan mengalami perubahan setiap tahun secara terus-menerus seiring dengan tuntutan dan tantangan dalam mempersiapkan sumber daya manusia yang berkualitas dan memiliki daya saing di era milenial global (Haerullah, 2020). Untuk mewujudkan hal tersebut, berbagai upaya dilakukan oleh pemerintah terutama untuk meningkatkan mutu pendidikan nasional. Beberapa program yang dianggap kursial/strategis yang dilakukan Pemerintah adalah dengan melakukan penyempurnaan kurikulum dan peningkatan peran guru dalam proses pembelajaran (Yusuf, 2018).

Menurut Lestari, (2020) bahwa peran guru merupakan salah satu pelaku utama dalam pendidikan sangat besar untuk mengembangkan potensi peserta didik tidak hanya potensi 
pengetahuan dan keterampilan, tetapi agar memiliki kemampuan seimbang antara nilai spiritual dan sosial. Sebagai seorang guru Pendidikan Agama Islam dan Budi Pekerti di UPTD SDN 01 Mungka Kecamatan Mungka Kabupaten Lima Puluh Kota, penulis merasakan permasalahan di kelas V di mana hasil belajar peserta didik mata pelajaran PAIdBP rendah yang terlihat jelas pada hasil Penilaian Harian (PH) pembelajaran PAIdBP materi Cita-citaku Menjadi Anak Sholeh.

Setiap pembelajaran khususnya pembelajaran agama hendaknya mampu menjabarkan nilainilai yang terkandung dalam kurikulum dan menerapkannya sesuai dengan kenyataan yang ada di sekitar peserta didik (Imelda, 2017). Maka dari pembelajaran PAIdBP harus kita maksimalkan karena merupakan salah satu dasar karakter peserta didik yang mampu memiliki kemampuan spiritual, sosial, pengetahuan dan keterampilan (Novianto \& Mustadi, 2015). PAIdBP diberikan kepada peserta didik dengan mengikuti aturan bahwa agama diturunkan serta diajarkan kepada manusia dengan tujuan untuk mewujudkan manusia beriman dan bertaqwa kepada Allah SWT, berakhlak mulia baik secara personal maupun sosial.

Dari hasil refleksi yang penulis lakukan, penulis menyadari bahwa perhatian peserta didik terhadap pembelajaran PAIdBP kurang. Hal ini tampak dari kurangnya antusias peserta didik saat proses pembelajaran sehingga mengakibatkan hasil belajar peserta didik juga kurang maksimal. Selanjutnya metode dalam pembelajaran PAIdBP yang dilaksanakan adalah konsep menghafal dan pemberian tugas. Hal ini kurang tepat bagi peserta didik sehingga mengakibatkan: (1) keaktifan peserta didik dalam pembelajaran masih belum terlalu tampak, (2) kemampuan belajar mandiri serta berpikir kritis peserta didik terhadap permasalahan yang dihadapinya masih kurang, (3) keberanian peserta didik dalam mengemukakan pendapat masih kurang, (4) rendahnya hasil belajar peserta didik yang dapat dilihat dari hasil PH PAIdBP di kelas V standar ketuntasan adalah 75 , tetapi masih banyak peserta didik yang memperoleh nilai di bawah standar ketuntasan yaitu dari 22 peserta didik hanya 9 anak yang sudah memenuhi standar ketuntasan. Artinya baru sekitar 40,9\% yang sudah memenuhi standar ketuntasan minimal yang telah ditetapkan. Selain dari hasil Penilaian Harian, hasil belajar bisa juga kita nilai dari perilaku sehari-hari pada peserta didik terutama di sekolah.

Melihat permasalahan diatas dan untuk mengatasinya perlu kiranya dikembangkan dan diterapkan suatu model pembelajaran yang lebih efektif dan banyak melibatkan peserta didik agar lebih aktif, kreatif dan menyenangkan serta mampu berpikir kritis dalam menghadapi suatu permasalahan dengan menggunakan model pembelajaran yang dapat diterapkan dalam kurikulum 2013 di Sekolah Dasar (SD). Seperti yang di ungkapkan oleh Anifa et al., (2021) bahwa hasil belajar yang rendah tidak dapat dipisahkan dari proses pembelajaran. Di dalam proses pembelajaran tercakup penggunaan metode, strategi serta model pembelajaran.

Metode ialah cara yang digunakan untuk mengimplementasikan rencana yang disusun dalam suatu kegiatan nyata agar secara optimal dapat mencapai tujuan yang telah disusun (Dudung, 2018). Senada dengan pendapat tersebut, Candra et al., (2020) menyatakan bahwa metode yaitu cara yang digunakan guru untuk menerapkan rencana pembelajaran yang telah disusun untuk mencapai tujuan pembelajaran yang telah ditetapkan. Hubungan metode pembelajaran dengan prinsip-prinsip belajar atau asas-asas belajar sangat erat. Hubungan metode pembelajaran dengan prinsip-prinsip belajar akan membangkitkan gairah peserta didik untuk belajar.

Sesuai dengan pendapat yang dikemukakan tersebut, maka seorang guru perlu melakukan berbagai cara agar proses pembelajaran PAIdBP bisa mencapai hasil belajar yang maksimal. Dan salah satu cara yang dapat dilakukan oleh guru agar peserta didik bisa maksimal dalam menerima pembelajaran PAIdBP adalah dengan penggunaan metode dan model pembelajaran yang tepat. Hal ini dikarenakan metode dan model pembelajaran ialah pola yang dipergunakan sebagai pedoman dalam perencanaan pembelajaran di kelas yang biasanya menggambarkan langkah- 
langkah atau prosedur yang ditempuh guru untuk menciptakan aktivitas pembelajaran yang efektif, efisien, dan menyenangkan bagi peserta didik (Siregar, 2021).

Di antara model pembelajaran yang dapat diterapkan pada mata pelajaran PAIdBP materi Cita-citaku Menjadi Anak Sholeh adalah model pembelajaran Problem Based Learning (PBL). Problem Based Learning atau pembelajaran berbasis masalah merupakan suatu model pembelajaran, yang mana peserta didik mengerjakan permasalahan otentik dengan tujuan untuk menyusun pengetahuan mereka sendiri, mengembangkan inkuiri dan keterampilan berpikir tingkat tinggi (Burhana et al., 2021)

Problem Based Learning merupakan salah satu model dalam pendekatan saintifik yang sesuai dengan kurikukulum 2013 sehingga peserta didik mampu mengembangkan pengetahuan yang dimiliki dengan pengalaman nyata dalam kehidupannya sehari-hari. Problem Based Learning merupakan suatu model pembelajaran yang menggunakan masalah dunia nyata sebagai suatu dasar bagi peserta didik untuk belajar berpikir kritis dan keterampilan pemecahan masalah serta memperoleh pengetahuan dan konsep esensial dari materi pelajaran (Karmana et al., 2020).

Selanjutnya dalam kaitannya dengan penerapan model Problem Based Learning dalam pembelajaran PAIdBP, menurut Azizah, (2020), Pendidikan Agama Islam adalah usaha berupa bimbingan dan asuhan terhadap peserta didik agar memahami dan mengamalkan ajaran agama Islam serta menjadikannya sebagai pandangan hidup, setelah menyelesaikan pendidikannya di tingkat pendidikan tertentu.

Pendidikan Agama Islam menurut Mahtum \& Fikri, (2020) adalah pendidikan yang berlandaskan ajaran Islam. Sejalan dengan pendapat tersebut, Ali, (2021) mengemukakan bahwa Pendidikan Agama Islam adalah usaha orang muslim dewasa yang beriman dan bertaqwa secara sadar untuk mengarahkan serta membimbing pertumbuhan dan perkembangan fitrahpeserta didik untuk menguasai kemampuan dasar beragama melalui ajaran Islam ke arah titik pertumbuhan dan perkembangan yang maksimal.

Menurut Nurhasanah \& Hidayati, (2021) Hasil belajar merupakan tolak ukur untuk menentukan tingkat keberhasilan peserta didik dalam memahami konsep dalam belajar, dimana hasil belajar ini dapat dilihat dari kemampuan peserta didik dalam memahami materi yang disampaikan guru dalam pembelajaran, yang terwujud melalui perubahan sikap, sosial, dan emosional peserta didik. Hal tersebut sejalan dengan pokok pikiran yang dikemukakan oleh Harefa, (2020) bahwa hasil belajar ialah berupa pengetahuan, tingkah laku, keterampilan serta kemampuan yang diperoleh peserta didik setelah menerima proses pembelajaran serta pengalaman belajar dan mampu mengimplementasikannya dalam kehidupan sehari-hari.

\section{METODE PENELITIAN}

Penelitian ini dilaksanakan di Kelas V UPTD SDN 01 Mungka Kecamatan Mungka Kabupaten Lima Puluh Kota. Subjek penelitian ini adalah peserta didik kelas V UPTD SDN 01 Mungka Kecamatan Mungka Kabupaten Lima Puluh Kota dengan jumlah peserta didik 22 orang, terdiri dari 12 orang laki-laki dan 10 orang perempuan. Penelitian dilaksanakan dalam 2 siklus dengan siklus pertama dua kali pertemuan dan siklus kedua dua kali pertemuan.

Jenis penelitian yang digunakan dalam penelitian ini ialah Penelitian Tindakan Kelas (PTK) serta menggunakan analisis data kualitatif dan kuantitatif untuk melakukan pengolahan data. Penelitian Tindakan Kelas ini menggunakan alur penelitian yang dikemukakan oleh Kemmis, Stephen and McTaggart, (2014), yang secara garis besar meliputi empat tahapan yaitu: (1) perencanaan, (2) pelaksanaan, (3) pengamatan, dan (4) refleksi.

Data penelitian dikumpulkan melalui pengamatan dan tes, dari setiap tindakan pelaksanaan serta perbaikan pembelajaran PAIdBP dengan model Problem Based Learning pada peserta didik 
kelas V UPTD SDN 01 Mungka Kecamatan Mungka Kabupaten Lima Puluh Kota. Data tersebut berupa deskripsi tentang hal-hal yang berkaitan dengan perencanaan, pelaksanaan, dan hasil belajar.

Sumber data penelitian ini adalah proses pembelajaran dengan menggunakan model Problem Based Learning (PBL) di kelas V UPTD SDN 01 Mungka kecamatan Mungka Kabupaten Lima Puluh Kota, yang meliputi perencanaan pembelajaran yang dibuat, pelaksanaan proses pembelajaran, dan hasil belajar yang diperoleh peserta didik. Data penelitian ini diperoleh dengan teknik tes dan non tes. Salah satu cara dalam teknik non tes adalah dengan menggunakan observasi yang dilakukan untuk mengamati aktivitas guru maupun peserta didik selama proses pembelajaran dengan menggunakan model Problem Based Learning berlangsung. Lembar observasi penerapan model Problem Based Learning (PBL) dari aspek guru sebagai peneliti dan peserta didik digunakan untuk mengetahui aktivitas guru sebagai peneliti selama berlangsungnya proses pembelajaran. Dalam lembar observasi diamati keadaan guru dan peserta didik dalam menerapkan model PBL dalam proses pembelajaran.

\section{HASIL DAN PEMBAHASAN}

\section{Hasil}

Perencanaan pelaksanaan pembelajaran Strategi Pembelajaran Inkuiri disusun dan diwujudkan dalam bentukrencana pelaksanaan pembelajaran (RPP). Rencana pelaksanaan pembelajaran ini disusun secara kolaboratif antara peneliti dan guru kelas UPTD SDN 01 Mungka Kecamatan Mungka Kabupaten Lima Puluh Kota. RPP disusun untuk 2 kali pertemuan masing-masing dalam waktu 4x35 menit. Materi pelajaran diambil berdasarkan Kurikulum 2013 Sekolah Dasar Edisi Revisi 2018. Hasil penelitian pada aspek pengamatan terhadap RPP siklus I pertemuan I memperoleh persentase $78,64 \%$ dan pada siklus I pertemuan II persentase yang diperoleh yaitu $84,56 \%$. Sedangkan skor rata-rata pada siklus I yaitu 78,96\%.

Berdasarkan rencana pelaksanaan pembelajaran yang telah disusun sebelumnya, pelaksanaan pembelajaran pada siklus I mengikuti langkah-langkah pembelajaran yang terdiri dari tiga tahap yaitu kegiatan pendahuluan, kegiatan inti, dan kegiatan penutup. Pelaksanaan pembelajaran menggunakan langkah-langkah model Problem Based Learning menurut Nakada et al., (2018) yaitu (a) orientasi peserta didik terhadap masalah, (b) mengorganisasi peserta didik untuk belajar, (c) membimbing penyelidikan individu atau kelompok, dan (d) mengembangkan/menyajikan hasil karya.

Berdasarkan pengamatan yang dilakukan terhadap RPP pada siklus I diperoleh rata-rata $85,22 \%$ dengan kualifikasi baik (B). Berdasarkan hasil pengamatan yang dilakukan terhadap aktivitas guru dalam pembelajaran siklus I diperoleh rata-rata 87,49\% dengan kualifikasi baik (B). Sedangkan hasil observasi pada aktivitas peserta didik siklus I diperoleh rata-rata 85,71\% dengan kualifikasi baik (B). Hasil belajar peserta didik pada pembelajaran PAIdBP dengan model PBL dapat dilihat dari penilaian sikap, pengetahuan, dan keterampilan. Hasil belajar peserta didik pada siklus I adalah 76,58.

Dari hasil pengamatan yang dilakukan observer pada siklus I diketahui bahwa RPP PAIdBP dengan model Problem Based Learning belum sesuai dengan yang diharapkan. Refleksi ini dilakukan secara kolaboratif antara guru sebagai peneliti dan 2 orang observer dari rekan sejawat guru kelas yang telah mengadakan pengamatan pada saat proses pembelajaran. Observer memberikan saran dan masukan atas hal yang terlupakan/tertinggal pada saat pembelajaran berlangsung. Berdasarkan hasil kolaborasi dan analisis observer dan peneliti masih banyak item yang belum tampak ataupun yang masih belum terlaksana. Dengan demikian, Kelemahan yang ditemui pada siklus I akan diperbaiki pada siklus II. 
Perencanaan tindakan pada siklus II dilakukan sebagai usaha untuk mengatasi kelemahan dan permasalahan yang ditemukan pada pelaksanaan pembelajaran siklus I. RPP disusun untuk 2 kali pertemuan masing-masing dengan alokasi waktu 4 x 35 menit. Materi pelajaran diambil berdasarkan Kurikulum 2013 Sekolah Dasar pada pembelajaran PAIdBP Kelas V semester I. RPP pada siklus II tidak jauh berbeda dengan perencanaan siklus I. Hanya saja kajian materi pada siklus II ini berbeda dengan siklus sebelumnya. Hasil penelitian pada pengamatan RPP siklus II memperoleh persentase $90,86 \%$. Dalam pelaksanaan tindakan, peneliti berperan sebagai guru serta 2 orang guru kelas sebagai pengamat (observer). Pelaksanaan pembelajaran disesuaikan dengan langkah-langkah pembelajaran dengan model Problem Based Learning.

Pengamatan dilakukan secara berkelanjutan mulai dari kegiatan pendahuluan sampai kegiatan penutup. Berdasarkan hasil pengamatan terhadap RPP siklus II diperoleh persentase penilaian 90,86\% dengan kriteria (SB). Berdasarkan hasil observasi terhadap aktivitas guru dalam pembelajaran siklus II diperoleh persentase penilaian 93,82\% dengan kualifikasi sangat baik (SB). Sedangkan hasil observasi pada aktivitas peserta didik diperoleh persentase 92,88\% dengan kualifikasi sangat baik (SB). Sedangkan untuk hasil belajar diperoleh rata-rata 86,28.

\section{Pembahasan}

Berdasarkan hasil penelitian pelaksanaan pembelajaran dengan model PBL pada pembelajaran PAIdBP kelas V UPTD SDN 01 Mungka Kecamatan Mungka Kabupaten Lima Puluh Kota terlihat bahwa guru telah membuat perencanaan dalam bentuk RPP. Perencanaan pembelajaran yang disusun guru terdiri dari beberapa komponen yaitu: (1) identitas, (2) kompetensi dasar, (3) Indikator, (4) tujuan pembelajaran, (5) materi pembelajaran, (6) sumber belajar, (7) media pembelajaran, (8) pendekatan dan model pembelajaran, (9) langkah pembelajaran, (10) implementasi PPK, dan 11) penilaian. Berdasarkan diskusi peneliti dengan observer, pada perencanaan pembelajaran yang dirancang peneliti pada siklus I dengan dua kali pertemuan sudah dapat dikatakan pada kualifikasi baik, namun masih ditemukan kelemahan yang harus diperbaiki pada siklus berikutnya.

Pelaksanaan pembelajaran PAIdBP dengan model PBL pada siklus I pembelajaran disajikan dalam 2 kali pertemuan. Pelaksanaan pembelajaran pada siklus 1 sudah sesuai dengan apa yang telah dituangkan dalam RPP, namun masih belum terlaksana secara maksimal. Pelaksanaan pembelajaran pada siklus I dibagi menjadi tiga tahap yaitu: pendahuluan, kegiatan inti, dan kegiatan penutup. Penyajian materi dengan menggunakan langkah-langkah PBL sudah sesuai dengan perencanaan awal namun pemakaian waktu tidak sesuai dengan alokasi waktu yang direncanakan, masih banyak peserta didik yang belum terlibat aktif dalam pembelajaran terutama saat melakukan diskusi kelompok hanya didominasi oleh beberapa peserta didik saja. Kurangnya rasa tanggung jawab peserta didik dalam berdiskusi, tampak dalam kelompok hanya dua atau tiga orang saja yang aktif bekerja sementara peserta didik yang lain meribut. Masih banyak peserta didik yang belum memahami langkah-langkah PBL sehingga pelaksanaan pembelajaran tidak dapat terlaksana sesuai dengan waktu yang direncanakan. Kelemahan yang terdapat pada pelaksanaan siklus I harus diperbaiki pada siklus berikutnya. Guru diharapkan dapat membimbing peserta didik dengan lebih baik agar tujuan pembelajaran dapat tercapai dengan maksimal.

Pembelajaran PAIdBP dengan model PBL pada siklus I sudah berjalan dengan baik. Namun hasil belajar siklus I menunjukkan bahwa belum keseluruhan peserta didik memahami materi yang diajarkan. Berdasarkan catatan pada lembar obrservasi dan diskusi peneliti dengan observer, penyebab dari belum tercapainya hasil belajar secara maksimal pada siklus I secara garis besar dikarenakan masih banyak peserta didik yang belum aktif selama proses pembelajaran dan belum terbiasa dengan belajar dengan model PBL.

Berdasarkan analisis penelitian siklus I pertemuan I diperoleh rata-rata hasil belajar peserta didik adalah 75,24 dengan kualifikasi cukup dan pada pertemuan II meningkat menjadi 80,56 
dengan kualifikasi cukup, dan masih ada 8 orang peserta didik yang belum mencapai hasil belajar yang diharapkan. Sedangkan hasil belajar yang diperoleh peserta didik pada pada siklus I didapatkan nilai rata-rata 77,92 dengan kualifikasi cukup.

Perencanaan pembelajaran siklus II tidak jauh berbeda dengan perencanaan pembelajaran siklus I. Perencanaan pembelajaran pada siklus II terlaksana dengan kualifikasi sangat baik. Perencanaan pembelajaran pada siklus II ini mengalami peningkatan dibandingkan siklus sebelumnya. Berdasarkan rekapitulasi data hasil observasi diketahui bahwa perolehan persentase skor pada siklus II adalah 93,64\% dengan kualifikasi sangat baik. Perbaikan-perbaikan yang ditemukan pada siklus II antara lain pada langkah pembelajaran yang lebih memperhatikan kesesuaian dan keruntutan materi serta implementasi PPK.

Berdasarkan pemaparan data di atas, dapat disimpulkan bahwa perencanaan pembelajaran PAIdBP dengan model PBL di kelas V UPTD SDN 01 Mungka Kecamatan Mungka Kabupaten Lima Puluh Kota telah terlaksana dengan kriteria sangat baik pada siklus II. Terdapat hubungan antara peningkatan perencanaan terhadap pelaksanaan pembelajaran dengan model PBL dan hasil belajar yang diperoleh peserta didik. Temuan penelitian di atas sejalan dengan pendapat Widiyanto \& Wahyuni, (2020) yang menyatakan bahwa perencanaan pembelajaran berisi tentang rangkaian kegiatan yang harus dilaksanakan untuk mencapai tujuan.

Pelaksanaan pembelajaran pada siklus II sesuai dengan perencanaan. Berdasarkan diskusi peneliti dengan observer, selama pelaksanaan pembelajaran ditemukan hal-hal sebagai berikut: (1) penyajian materi dengan menggunakan langkah-langkah PBL sudah sesuai dengan perencanaan yang dibuat, (2) guru sudah memotivasi peserta didik untuk terlibat dalam pemecahan permasalahan dan bekerjasama dalam diskusi kelompok, (3) guru telah memberikan penguatan materi pada saat mengakhiri pembelajaran, (4) guru sudah dapat menguasai kelas dan melaksanakan pembelajaran dengan baik, (5) sebagian besar peserta didik sudah terlihat aktif terlibat dalam pembelajaran terutama saat melakukan diskusi kelompok, (6) peserta didik sudah memiliki rasa tanggung jawab dalam berdiskusi. Pembelajaran PAIdBP dengan menggunakan PBL pada siklus II ini sudah berjalan dengan baik, ini dapat dibuktikan dengan nilai yang diperoleh peserta didik sudah meningkat yaitu dengan rata-rata hasil belajar peserta didik yaitu 86,28 dengan kualifikasi baik..

\section{KESIMPULAN}

Pelaksanaan pembelajaran PAIdBP menggunakan model Problem Based Learning (PBL) di kelas V UPTD SDN 01 Mungka Kecamatan Mungka Kabupaten Lima Puluh Kota terdiri dari kegiatan pendahuluan, kegiatan inti, dan kegiatan penutup. Pelaksanaan pembelajaran PAIdBP dengan model PBL dilaksanakan dengan langkah-langkah: (1) mengorientasi peserta didik pada masalah, (2) mengorganisasi peserta didik untuk belajar, (3) membimbing penyelidikan individu dan kelompok, (4) mengembangkan dan menyajikan hasil karya, (5) menganalisis dan mengevaluasi proses pemecahan masalah.

Hasil pengamatan dari pelaksanaan pembelajaran dengan model PBL dapat diamati dari aktivitas guru dan aktivitas peserta didik. Aktivitas guru pada siklus I menunjukkan bahwa pelaksanaan pembelajaran belum maksimal persentase yang diperoleh adalah $87,49 \%$ dengan kualifikasi baik. Sedangkan pada siklus II persentase yang diperoleh adalah 93,82\% dengan kualifikasi sangat baik. Sedangkan aktivitas peserta didik pada siklus I persentase yang diperoleh adalah $85,71 \%$. Sedangkan pada siklus II persentase yang diperoleh adalah $92,85 \%$ dengan kualifikasi sangat baik. Dari hal ini terlihat bahwa ada peningkatan dalam pelaksanaan pembelajaran tematik terpadu menggunakan model Problem Based Learning di kelas V UPTD SDN 01 Mungka Kecamatan Mungka Kabupaten Lima Puluh Kota. 
Pembelajaran PAIdBP dengan model Problem Based Learning (PBL) di kelas V UPTD SDN 01 Mungka Kecamatan Mungka Kabupaten Lima Puluh Kota dapat meningkatkan hasil belajar peserta didik. Hal ini dapat dilihat dari rekapitulasi hasil belajar peserta didik. Pada siklus I memperoleh rata-rata kelas 77,92 dan siklus II memperoleh rata-rata kelas 86,28. Hal ini membuktikan bahwa penelitian yang telah dilakukan di UPTD SDN 01 Mungka Kecamatan Mungka Kabupaten Lima Puluh Kota dengan menggunakan model Problem Based Learning (PBL) telah berhasil meningkatkan hasil belajar peserta didik pada pembelajaran PAIdBP di kelas V UPTD SDN 01 Mungka Kecamatan Mungka Kabupaten Lima Puluh Kota.

Selanjutnya peneliti juga memberikan saran agar guru menyiapkan segala keperluan dan fasilitas yang mendukung dalam pelaksanaan pembelajaran model Problem Based Learning, guru terus mengontrol hasil belajar yang diperoleh peserta didik agar senantiasa istiqamah atau meningkatkan kembali kemampuannya, memberikan motivasi peserta didik untuk terlibat aktif dalam proses pembelajaran dan mengarahkan peserta didik untuk memiliki rasa percaya diri dalam pembelajaran, serta membantu peserta didik untuk mampu mengambil kesimpulan atas permasalahan terkait materi pembelajaran sehingga setelah pembelajaran peserta didik memiliki karakter diri..

\section{REFERENSI}

Ali, I. (2021). Pembelajaran Kooperatif (Cooperativelearning) Dalam Pengajaran Pendidikan Agama Islam. Jurnal Mubtadiin, 7(01), 247-264.

Anifa, R. T., Zainil, M., \& Pusra, D. (2021). Peningkatan Hasil Belajar Siswa dalam Pembelajaran Tematik Terpadu Menggunakan Model Pembelajaran Kooperatif Tipe Make A Match Kelas IV SD Negeri 20 Indarung. Jurnal Pendidikan Tambusai, 5(2), 3278-3283.

Azizah, F. N. (2020). Strategi Meaningfull Learning dalam Proses Belajar Mengajar Pendidikan Agama Islam di Tengah Pandemi Covid-19. Journal of Islamic Education Research, 1(3), 215224.

Burhana, A., Octavianti, D., Anggraheni, L. M. R., Ashariyanti, N. D., \& Mardani, P. A. A. (2021). Model Problem Based Learning (PBL) Untuk Meningkatkan Cara Berpikir Kritis Siswa di Sekolah Dasar. SNHRP, 3, 302-307.

Candra, P. N., Soepriyanto, Y., \& Praherdhiono, H. (2020). Pedagogical Knowledge (PK) Guru Dalam Pengembangan dan Implementasi Rencana Pembelajaran. Jurnal Kajian Teknologi Pendidikan, 3(2), 166-177.

Dudung, A. (2018). Kompetensi Profesional Guru. JKKP Jurnal Kesejabteraan Keluarga Dan Pendidikan). https://doi.org/10.21009/jkkp.051.02

Haerullah, H. (2020). Dimensi Perkembangan Pendidikan Formal dan Non Formal. Jurnal Edukasi Nonformal, 1(2), 199-207.

Harefa, D. (2020). Peningkatan Hasil Belajar Siswa Dengan Pembelajaran Kooperatif Make A Match Pada Aplikasi Jarak Dan Perpindahan. Geography: Jurnal Kajian, Penelitian Dan Pengembangan Pendidikan, 8(1), 1-18.

Imelda, A. (2017). Implementasi Pendidikan Nilai Dalam Pendidikan Agama Islam. AlTadzkiyyah: Jurnal Pendidikan Islam, 8(2), 227-247.

Karmana, I. W., Dharmawibawa, I. D., \& Hajiriah, T. L. (2020). Efektivitas strategi PBL berbasis potensi akademik terhadap keterampilan pemecahan masalah dan berpikir kritis siswa SMA pada topik lingkungan. Jurnal Ilmiah Mandala Education, 6(1).

Kemmis, Stephen and McTaggart, R. (2014). The Action Research planner. Springer Singapore Heidelberg.

Lestari, N. A. D. (2020). Peran Guru Pendidikan Agama Islam dalam Menanamkan Nilai-Nilai Karakter Peserta Didik Kelas $V$ di SDN 3 Adipuro. IAIN Metro. 
Mahtum, R., \& Fikri, A. R. (2020). Teknik Pembelajaran pada Aspek-Aspek Pendidikan Islam Dalam Surah Luqman Ayat 13-19. Tarbiyatuna: Kajian Pendidikan Islam, 4(1), 76-94.

Nakada, A., Kobayashi, M., Okada, Y., Namiki, A., \& Hiroi, N. (2018). Project-based learning. Journal of the Medical Society of Toho University. https://doi.org/10.14994/tohoigaku.2017-010

Novianto, A., \& Mustadi, A. (2015). Analisis buku teks muatan tematik integratif, scientific approach, dan authentic assessment sekolah dasar. Jurnal Kependidikan: Penelitian Inovasi Pembelajaran, 45(1).

Nurhasanah, I., \& Hidayati, N. (2021). Analisis Hasil Belajar Matematika Siswa SMPN Kelas VIII pada Materi Persegi Panjang. MAJU: Jurnal Ilmiah Pendidikan Matematika, 8(1).

Siregar, R. L. (2021). Memahami tentang Model, Strategi, Metode, Pendekatan, Teknik, dan Taktik. HIKMAH: Jumal Pendidikan Agama Islam, 10(1), 63-75.

Widiyanto, I. P., \& Wahyuni, E. T. (2020). Implementasi Perencanaan Pembelajaran. Satya Sastraharing: Jurnal Manajemen, 4(2), 16-35.

Yusuf, W. F. (2018). Implementasi Kurikulum 2013 (K-13) Pada Mata Pelajaran Pendidikan Agama Islam Sekolah Dasar (SD). Jurnal Al-Murabbi, 3(2), 263-278. 